

\section{Kalpataru}

Jurnal Sejarah dan Pembelajaran Sejarah

Volume 7, Nomor 1, Juli 2021

\section{Chief Editor}

Drs. Sukardi, M.Pd.

\section{Editor}

Dr. Muhamad Idris, M.Pd.

Eva Dina Chairunisa, M.Pd.

Jeki Sepriady, S.Pd.

\section{Reviewer}

Dr. Tahrun, M.Pd.

Drs. Supriyanto, M.Hum.

Dra. Retno Purwati, M.Hum.

Dr. Nor Huda Ali, M.Ag., M.A.

Dr. Budi Agung Sudarman, S.S., M.Pd.

Dr. Purmansyah, M.A.
(Universitas PGRI Palembang)

(Universitas Sriwijaya Palembang)

(Balai Arkeologi Sumatera Selatan)

(Masyarakat Sejarawan Indonesia Sumsel)

(Balai Bahasa Provinsi Sumatera Selatan)

(Universitas Muhammadiyah Palembang)

\section{Alamat Redaksi \\ Program Studi Pendidikan Sejarah \\ Fakultas Keguruan dan IImu Pendidikan Universitas PGRI Palembang \\ Telp. 0711-510043 \\ Email: jurnalkalpatarusejarah@gmail.com \\ Website: https://jurnal.univpgri-palembang.ac.id/index.php/Kalpa}




\section{Kalpataru}

JURNAL SEJARAH DAN

PEMBELAJARAN SEJARAH

Terbit dua kali setahun pada Juli dan Desember

Diterbitkan oleh:

Program Studi Pendidikan Sejarah Jurusan Pendidikan IPS

Fakultas Keguruan

dan IImu Pendidikan

Universitas PGRI Palembang

\section{DAFTAR ISI}

Nilai Budaya Masjid Jami' Sungai Lumpur Kelurahan II Ulu Palembang Sebagai Sumber Pembelajaran Sejarah

Maya Susanti, Muhamad Idris, Aan Suriadi.... $1-9$

Analisis Konsep Gender Dalam Undang-Undang Simbur Cahaya Sebagai Sumber Pembelajaran Sejarah Ruli Annisa, Muhamad Idris, Kabib Sholeh .... $10-18$

Perbedaan Model Pembelajaran Student Teams Achievement Divisions (STAD) dengan Model Pembelajaran Jigsaw Terhadap Hasil Belajar Siswa Pada Mata Pelajaran Sejarah di SMA Negeri 2 Mesuji Taufik Sidiki Al-Haq, Nur Ahyani, Ida Suryani.

Pengaruh Pemanfaatan Media Youtube Terhadap Hasil Belajar Siswa Mata Pelajaran Sejarah di SMK PGRI 2 Palembang

Riska Anggraini, Nur Ahyani, Ida Suryani.

Pengaruh Metode Pembelajaran Daring Terhadap Hasil Belajar Siswa Pada Mata Pelajaran Sejarah di Kelas XI IPA SMA Shailendra Palembang

Christina Leovita Saragih, Nur Ahyani, Aan Suriadi. $37-42$

Pengembangan Media Pembelajaran Digital Bukti-bukti Bangunan Masjid Kuno di Palembang Berbasis Android Varokah Widiyanti, Eva Dina Chairunisa, Ahmad Zamhari .....

Gambar Cover:

Pohon Kalpataru

Candi Prambanan

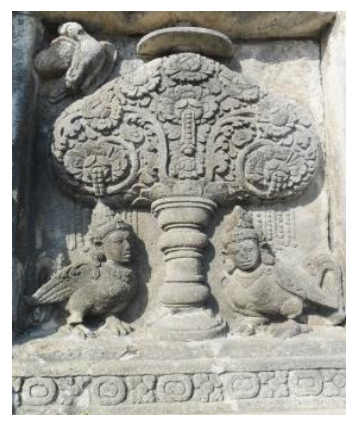

Koleksi: Muhamad Idris
Hubungan Jawa-Melayu Dalam Dunia Arsitektur Melayu Sumatera Selatan

Reyvaldi Uyun, Muhamad Idris, Ahmad Zamhari.

Kondisi Politik Orde Baru di Gorontalo Tahun 19681998

Ferrari Yuliawati S, Suryo Ediyono.

Nilai-nilai Sejarah dan Budaya Ikonografi Megalith di Lahat Sebagai Sumber Pembelajaran Sejarah Nasional Jainal Arifin, Sukardi, Dina Sri Nindiati.

Minat Siswa Terhadap Sejarah dan Budaya Palembang di SMA Negeri 15 Palembang Febbi Astuti, Muhamad Idris, Kabib Sholeh. $.77-82$ 


\title{
NILAI BUDAYA MASJID JAMI' SUNGAI LUMPUR KELURAHAN II ULU PALEMBANG SEBAGAI SUMBER PEMBELAJARAN SEJARAH
}

\author{
Maya Susanti \\ Mahasiswa Program Studi Pendidikan Sejarah, FKIP Universitas PGRI Palembang \\ Email: susantimaya0112@gmail.com \\ Muhamad Idris \\ Dosen Program Studi Pendidikan Sejarah, FKIP Universitas PGRI Palembang \\ Email: muhamadidris_sj@univpgri-palembang.ac.id \\ Aan Suriadi \\ Dosen Program Studi Pendidikan Sejarah, FKIP Universitas PGRI Palembang \\ Email: aansuriadi@yahoo.com
}

\begin{abstract}
ABSTRAK
Masjid Jami' Sungai Lumpur Palembang adalah salah satu masjid tertua yang berada di Kota Palembang (1259 H/1837 M) hingga sampai saat ini Masjid Jami' Sungai Lumpur masih terawat dengan rapi. Permasalahan penelitian adalah untuk mengetahui nilai budaya Masjid Jami' Sungai Lumpur sebagai sumber pembelajaran sejarah. Tujuan penelitian ini adalah untuk mengetahui nilai budaya Masjid Jami' Sungai Lumpur sebagai sumber pembelajaran sejarah. Metode penelitian adalah metode deskriptif kualitatif. Teknik pengumpulan data yang digunakan observasi, dokumentasi, wawancara dan kajian pustaka. Teknik analisis data dengan reduksi data, penyajian data, dan verifikasi. Dari hasil penelitian dapat disimpulkan Masjid Jami' Sungai Lumpur memiliki nilai sejarah syiar Islam di Kota Palembang pada abad 19 Masehi. Masjid Jami' Sungai Lumpur memiliki nilai budaya berupa nilai tangible dan intangible. Nilai budaya tangible Masjid Jami' Sungai Lumpur antara lain seni arsitektur bangunan masjid, seni ukiran, seni lukis, benda upacara keagamaan (bedug, bendera, tongkat, panggung kotbah). Nilai budaya intangible Masjid Jami' Sungai Lumpur antara lain: konsep sembilan, konsep kearifan lingkungan pelestarian lahan basah. Nilai sejarah dan nilai budaya Masjid Jami' Sungai Lumpur dapat dijadikan sumber ajar, materi pengayaan materi penyebaran agama Islam dan sejarah lokal.
\end{abstract}

Kata Kunci: Masjid Jami' Sungai Lumpur, Nilai Budaya, Pembelajaran Sejarah.

\section{A. PENDAHULUAN}

Kondisi secara geografis wilayah Sumatera Selatan atau tepatnya Palembang yang menjadi pusat Kerajaan Sriwijaya memang tidak diragukan lagi sebagai jalur lalu lintas pelayaran perdagangan internasional pada masa itu. Kondisi yang banyak aliran sungai menghubungkan antara satu sungai dengan sungai yang lain semuanya bermuara menuju satu sungai yaitu di sungai Musi dan dilanjutkan menuju laut (Sholeh, 2016:12).

Masuknya Islam ke Sumatera Selatan khususnya Palembang terjadi pada abad ke-7 Masehi, dengan jalan damai melalui pelayaran dan perdagangan yang dibawa oleh bangsa Arab. Kelompok pedagang muslim ini selain berdagang, melakukan pula hubungan dengan kelompok masyarakat lainnya sehingga secara berangsur-angsur dan sesuai dengan kondisi setempat pada masa itu berkembanglah agama Islam secara lambat laun sepanjang abad ke-7 Masehi hingga abad ke-14 Masehi (Bakti, 2012:7).

Penyebaran Islam di Sumatera Selatan dimulai pada masa Kerajaan Sriwijaya pada abad ke-10 Masehi, para pedagang muslim dari Timur Tengah, terutama Arab dan Persia, sudah datang ke Palembang. Namun Islam menyebar dengan cepat baru dalam abad-abad menjelang kejatuhan Kerajaan Sriwijaya pada abad ke-14 Masehi. Palembang menjadi kubu Islam yang kuat dengan bangkitnya Kesultanan Palembang 


\section{Kalpataru, Volume 7, Nomor 1, Juli 2021 (1-9)}

awal abad ke-17 Masehi. Keberadaan pedagang Arab terutama pada masa Kesultanan Palembang yang berperan dalam menyebarkan agama Islam di Palembang bahkan sampai ke daerah pedalaman diantaranya adalah Kyai Merogan (1811-1901). Nama aslinya adalah Masagus Haji Abdul Hamid bin Masagus Mahmud, ia dikenal sebagai pedagang yang kaya raya sehingga dia dapat membangun dua masjid pada masanya. Masjid ini dikenal dengan nama Masjid Marogan dan Masjid Lawang Kidul yang sekarang termasuk masjid tua dan mempunyai nilai historis.

Para pedagang atau saudagar Arab Palembang terbukti mempunyai pengaruh besar dalam proses pengislaman masyarakat Palembang. Setelah keruntuhan Kesultanan Palembang (1821 Masehi), kehidupan saudagar Arab (perekonomian mereka) terus meningkat sehingga mereka tidak segan-segan memberikan modal dagang kepada penduduk setempat dengan syarat mereka mau masuk agama Islam. Untuk menunjang kegiatan pelajaran agama mereka mendirikan masjidmasjid disekitar perkampungan Arab tepat kediamannya. Salah satunya adalah masjid yang dikenal dengan nama Masjid Sungai Lumpur terletak di kelurahan 11 Ulu di tengah perkampungan Arab. Masjid tersebut didirikan oleh seorang saudagar Arab yang kaya yakni, Sayyid Abdullah bin Salim Alkaf pada tahun 1289 H/1872 M (Rochmiatun, 2017:6).

Masyarakat yang shalat di masjid ini sering datang dari daerah seberang llir dengan menggunakan perahu. Masjid Jami' Sungai Lumpur tentunya mempunyai nilai sejarah tersendiri, hal tersebut dikarenakan Masjid Jami' Sungai Lumpur dibangun pada masa Sultan Mahmud Badaruddin II, selain itu masjid tersebut juga memiliki arsitektur yang berbeda dengan masjid lainnya yang ada di Palembang pada umumnya, seperti yang diketahui bahwa bangunan Masjid Jami' Sungai Lumpur terdiri dari beberapa tiang yang berbentuk bulat, dan berdiameter lebih kurang satu setengah meter, dan terdapat lampu-lampu, masjid ini sudah mengalami beberapa kali renovasi, hal ini dikarenakan kondisi jama'ah yang semakin hari semakin bertambah. Dari pengamatan penulis masjid ini memiliki keunikan tersendiri yaitu karena letaknya yang sangat dekat dengan rumah penduduk, dan mempunyai bilik-bilik yang dimana disetiap penjuru mempunyai pintu untuk masuk ke dalam masjid tersebut.

Masjid ini memiliki nilai budaya tersendiri yaitu selain digunakan sebagai tempat ibadah oleh masyarakat sekitar digunakan juga sebagai sekolah, tempat para ulama besar berkumpul dalam mengajarkan syari'at Islam, sebagai tempat konsultasi dan komunikasi, tempat menyalurkan santunan sosial, tempat pernikahan, dan pusat penerangan dan pembelaan agama (Paramita, 2018:102).

\section{B. METODE PENELITIAN}

Berdasarkan rumusan masalah dalam penelitian ini mendeskripsikan secara rinci dan mendalam tentang apakah nilai budaya pada Masjid Jami' Sungai Lumpur Kelurahan 11 Ulu Palembang yang dapat dijadikan sumber pembelajaran sejarah. Untuk memahami hal tersebut dilakukan penelitian secara mendalam dengan menggunakan metode deskriprif kualitatif.

Teknik pengumpulan data dapat dilakukan dalam berbagai setting. Berbagai sumber, dan berbagai cara. Pengumpulan data berdasarkan tekniknya yaitu melalui: observasi, dokumentasi dan wawancara.

Observasi: mendatangi tempat lokasi penelitian dan melihat apa yang menjadi permasalahan dilapangan. Wawancara: digunakan sebagai teknik pengumpulan data apabila peneliti ingin melakukan studi pendahuluan untuk menemukan masalah yang harus diteliti. Dokumentasi: digunakan untuk mendapatkan data yang ada dilapangan seperti arsip, foto, dan dokumen yang menyimpan tentang penelitian.

\section{HASIL DAN PEMBAHASAN}

Masjid Jami' Sungai Lumpur tepatnya terletak di lorong pabrik Kelurahan 11 Ulu yang berdekatan dengan pasar 10 Ulu Palembang dan tidak jauh dengan Jembatan Ampera. Bangunan pada masjid ini keseluruhan berukuran 40 x 40 meter. Awal berdirinya Masjid Jami' Sungai Lumpur ini dibangun oleh Sayid 


\section{Kalpataru, Volume 7, Nomor 1, Juli 2021 (1-9)}

Abdullah bin Salim Alkaff seorang ulama penyebar Islam dan seorang pengusaha.

\section{Fungsi Keagamaan Ibadah}

Ibadah secara bahasa adalah tunduk atau merendahkan diri. Sedangkan secara istilah atau syara', ibadah merupakan suatu ketaatan yang dilakukan dan dilaksanakan sesuai perintah-Nya, merendahkan diri kepada Allah SWT dengan kecintaan yang sangat tinggi dan mencakup atas segala apa yang Allah ridhai baik yang berupa ucapan atau perkataan maupun perbuatan yang dhahir ataupun bathin.

\section{Kegiatan Keagamaan}

Menurut Kamus Besar Bahasa Indonesia (KBBI) pengertian agama adalah sistem yang mengatur tata keimanan (kepercayaan) dan peribadatan kepada Tuhan Yang Maha Kuasa serta tata kaidah yang berhubungan dengan pergaulan manusia serta lingkungannya. Bentuk kegiatan keagamaan yang bertujuan untuk membiasakan seseorang atau kelompok dalam mewujudkan keimanan dan ketakwaan kepada Allah. Dalam praktiknya dapat terbagi atas tiga bagian yaitu harian, mingguan, dan tahunan.

\section{Amal}

Rukun ketiga dalam rukun islam adalah zakat. Setiap muslim yang mampu wajib menzakati hartanya sebanyak $2,5 \%$ dari jumlah hartanya. Masjid sebagai pusat dari komunitas umat Islam, menjadi tempat penyaluran zakat bagi yatim piatu dan fakir miskin. Pada saat Idul Fitri, masjid menjadi tempat penyaluran zakat fitrah dan membentuk panitia amil zakat. Panitia zakat, biasanya dibentuk secara lokal oleh orang-orang atau para jemaah yang hidup di sekitar lingkungan masjid. Begitu pula dalam pengelolaannya. Namun, untuk masjid-masjid besar seperti di pusat kota, biasanya langsung ditangani oleh pemerintah daerah setempat.

\section{Fungsi Sosial \\ Pendidikan}

Masjid berfungsi sebagai tempat untuk belajar mengajar, khususnya ilmu agama yang merupakan fardlu 'ain bagi umat Islam. Di samping itu juga ilmu-ilmu lain, baik ilmu alam, sosial, humaniora, keterampilan dan lain sebagainya dapat diajarkan di masjid. Sebagai tempat pembinaan jama'ah. Dengan adanya umat Islam di sekitarnya, masjid berperan dalam mengkoordinir mereka guna menyatukan potensi dan kepemimpinan umat. Sehingga masjid menjadi basis umat Islam yang kokoh. Di samping itu, lima kali sehari muslim datang ke masjid untuk shalat berjama'ah. Pembentukan jama'ah dalam masjid bertujuan untuk kelanjutan di luar masjid sehingga menjadi kesatuan muslim yang kokoh, kesatuan sosial itu bukan bersifat satu. Masjid pusat ibadah dan kebudayaan Islam, karena semua orang yang diikat oleh masjid itu dapat berasal dari bermacam suku bangsa. Sebagai pusat dakwah dan kebudayaan Islam. Masjid merupakan jantung kehidupan umat Islam yang selalu berdenyut untuk menyebarluaskan dakwah Islamiyah dan budaya Islami.

\section{Arsitektur \\ Bangunan}

Masjid dalam sejarahnya mempunyai arti penting dalam kehidupan umat Islam, hal ini karena masjid sejak masa Rasulullah SAW, telah menjadi sentra utama seluruh aktivitas umat Islam generasi awal, bahkan, masjid kala itu menjadi "fasilitas" umat Islam mencapai kemajuan peradaban. Pada masa Rasulullah SAW, masjid berfungsi sebagai sentra kegiatankegiatan pendidikan, yakni tempat pembinaan dan pembentukan karakter umat. Bahkan lebih strategis, pada masa Rasulullah SAW, masjid menjadi sentra kegiatan politik, ekonomi, sosial dan budaya umat. Hal ini karena disetiap harinya umat Islam berjumpa dan mendengar arahan-arahan Rasulullah SAW, tentang hal ini. Sekarang ini, fungsi masjid mulai menyempit, tidak sebagaimana fungsinya pada masa Rasulullah SAW, hidup yang menjadi sentra seluruh kegiatan umat Islam. Pengertian masjid tempat shalat umat Islam disebut masjid, tidak disebut marka (tempat ruku') atau kata lain semisal dengannya yang menjadi rukun shalat.

Sujud juga dapat diartikan sebagai perbuatan meletakkan kening ke tanah, secara maknawi mengandung arti menyembah. Sedangkan sajadah berasal dari kata sajjadatun yang mengandung arti tempat yang 


\section{Kalpataru, Volume 7, Nomor 1, Juli 2021 (1-9)}

dipergunakan untuk sujud, mengkerucut maknanya menjadi selembar kain atau karpet yang dibuat khusus untuk shalat orang per orang. Karena itu, karpet masjid yang lebar, meski fungsinya sama tetapi tidak disebut sajadah.

\section{Ragam Hias Lukisan \\ Bentuk Bangunan Masjid}

Arsitektur masjid terbentuk dengan sangat kuat oleh tradisi regional sesuai waktu dan tempat di mana masjid tersebut dibangun. Oleh karena itu, gaya, tata letak dan dekorasinya bisa sangat beragam (bervariasi). Namun demikian, karena fungsi umum bangunan masjid sebagai tempat shalat berjamaah maka beberapa fitur arsitektur tertentu bisa muncul pada bangunan masjid di seluruh dunia. Di Indonesia, arsitektur bangunan masjid banyak dipengaruhi oleh tradisi dan budaya yang merupakan peninggalan kejayaan kerajaan-kerajaan Islam, sehingga bangunan masjid yang dibangun sebelum abad ke-20 Masehi yang diistilahkan dengan sebutan "masjid lama" mempunyai bentuk yang sangat kuat dipengaruhi oleh tradisi dan budaya masyarakat setempat. Elemen dasar dari bangunan masjid adalah ruang sholat, tempat di mana jamaah bisa menghadap ke arah kiblat, bangunan Ka'bah di Kota Mekkah, yang orientasi didefinisikan oleh keberadaan mihrab (ceruk) di dinding kiblat tempat Imam memimpin sholat. Mimbar tempat khotib memberikan khutbah ditempatkan di sebelah kanan mihrab. Ruang untuk sholat bisa dikelilingi dinding, tiang-tiang, atau arcade. Ruang ini diakses melalui pintu masuk (gerbang) yang berbeda dalam desain, di beberapa negara, pintu gerbang masuk memiliki nilai arsitektur untuk memperoleh simbolis yang besar. Bentuk keruangan masjid cenderung melebar dari dalam. Pemilihan bentuk spasial ini dimaksudkan untuk memberi lebih banyak kesempatan jamaah untuk lebih dekat dengan dinding kiblat yang diketahui karena manfaat surgawinya. Pola perkembangan serta pemilihan bentuk arsitektur Masjid Jami' Sungai Lumpur yang dilakukan dalam rentang waktu yang panjang bisa dibedakan atas proses penambahan bangunan membentuk beberapa lapisan yang membalut bangunan inti, serta upaya membuka balutan bangunan tambahan untuk mengungkap keaslian dan citra bangunan sebenarnya. Upaya paling mudah untuk melakukan identifikasi perkembangan bangunan masjid paling dilakukan terhadap keberadaan dan posisi dinding kiblat dengan mihrab di bagian tengahnya, sebagai elemen penting arsitektur bangunan masjid yang memiliki kekuatan bahkan menjadi simbol, yang secara turun temurun ada dan terus menerus muncul. Perjalanan waktu menunjukkan bahwa keberadaan dinding kiblat beserta bangunan "penampil" diarah Barat bangunan inti Masjid Jami' Sungai Lumpur Palembang tetap bertahan selama ratusan tahun dalam proses perkembangan yang terjadi berulang kali sampai perwujudannya yang terakhir. Mihrab Masjid Jami' Sungai Lumpur merupakan mihrab asli yang belum mengalami perubahan bentuk, namun telah beberapa kali mengalami pengecatan dan perbaikan sampai dalam bentuk yang sekarang. Mihrab masjid berbahan kayu tembesu yang dihiasi ukiran motif sulur dan buah, daun anggur yang dicat prada emas. Beberapa bagian dihiasi dengan ornamen laquer bunga dan daun.

\section{Atap}

Bentuk atap Masjid Jami' Sungai Lumpur terbagi menjadi dua jenis yaitu tajug tumpang tiga yang menaungi ruang utama masjid dan limasan yang menaungi ruang serambi masjid. Bentuk atap tajug dengan model piramida mengerucut disatu titik puncak sejajar dengan keempat soko guru pada tengah ruang utama (ruang dalem dalam terminologi Jawa) peneliti menemukan nilai-nilai filosofis yang ditunjukkan oleh eksistensi dari atap tajug yang menjadi atap utama masjid dan merupakan bentuk yang paling dominan, yaitu: dengan bentuk atap tajug piramida berjenjang tiga semakin ke atas semakin mengerucut/mengecil, ada titik puncak atau pencapaian akhir yang disimbolkan dengan mahkota. Atap masjid vertikalitas bentuk atap tajug yang mengarah ke atas, menggambarkan adanya unsur transenden/immaterial berkenaan dengan pesan yang disampaikan, yaitu tujuan dari ibadah kepada Allah SWT. Horizontalitas bentuk atap limasan yang disimbolkan dengan 


\section{Kalpataru, Volume 7, Nomor 1, Juli 2021 (1-9)}

bubungan (molo), menggambarkan adanya unsur immanen/material berkenaan hubungan sesama manusia dan hubungan dengan lingkungannya. Bentuk penampang bawah atap tajug adalah bujursangkar, hal ini disebabkan oleh bentuk denah ruang utama yang juga berbentuk bujursangkar.

\section{Tiang}

Masjid Jami' Sungai Lumpur merupakan masjid tipe Jawa yang beratap limasan, walaupun pada beberapa bagian telah mengalami perubahan dan pergantian dan dihilangkan sehingga mengaburkan bentuk aslinya. Contohnya hilangnya lampu-lampu asli dari minyak damar (setelup) yang dapat dinaikturunkan pada saat menghidupkan dan mematikannya. Dan yang tersisa hanya sisasisa besi penggantungnya saja. Tiang-tiang masih dalam bentuk aslinya, hanya batu tapaknya yang dilapisi semen dan keramik. Namun secara keseluruhan masih dalam bentuk asli.

\section{Menara}

Menara adalah salah satu arsitektur Islam. Menara merupakan struktur tunggal yang tinggi menjulang dan menonjol keluar dari lingkungannya. Sebuah menara biasanya memiliki unsur-unsur, base, shaft, balkon dan mahkota, kubah, kepala menara. Dalam Islam menara selalu disandingkan dengan masjid dan digunakan oleh Muadzin untuk mengumandangkan adzan, memanggil umat Islam shalat berjamaah. Indonesia memiliki arsitektur masjid kuno yang khas yang membedakannya dengan bentuk-bentuk masjid di negara lain. Tipe masjid Indonesia berasal dari pulau Jawa, sehingga orang dapat menyebut masjid tipe Jawa. Ciri khas masjid tipe Jawa: 1) Menara dengan gaya menara kulkul Bali; 2) Menara yang mendapat pengaruh Portugis; 3) Menara yang mendapat pengaruh Belanda dengan bentuk seperti mercusuar; 4) Menara yang mendapat pengaruh gaya Hadramaut (Arab); 5) Menara yang mendapat pengaruh India (Sutrisno, 2013:4-7).

\section{Tempat Wudhu dan Kolam Kuno}

Pemisahan tempat wudhu dengan kamar mandi. Tempat wudhu berada di atas sejajar dengan lantai utama bangunan, sedangkan untuk kamar mandi berada di bawah tempat wudhu sejajar dengan permukaan tanah (Bahar, 2012:12).

Terdapat halaman yang cukup luas melebihi luas lahan bangunan masjid. Halaman ini tidak beratap dan sangat panas diwaktu siang hari, sedangkan dimalam hari hempasan angin cukup kencang dan dingin. Kondisi ini menjadikan halaman ini kurang terawat kebersihannya. Terlebih lagi ditambah desain lantai yang bergaris-garis berlubang, sebenarnya desain ini digunakan untuk drainase halaman agar tidak ada air yang menggenang, namun pada kenyataannya garis-garis tersebut dipenuhi sampah, daun-daun kering dan rumput liar. Masjid ini dahulu memiliki kolam kuno dahulunya yang luas pada bagian tengah halaman. Kolam memang identik dengan bangunan Islam, keberadaan kolam harus selalu terawat dan bersih yang mencerminkan kebersihan kesucian Islam, namun tidak demikian yang terjadi pada kolam masjid ini. Pada tempat wudhu tidak ada tempat untuk mencuci kaki yang kotor, baik berupa kolam pencuci kaki maupun kran sebelum masuk area wudhu, sehingga lantai suci bisa saja menjadi najis walaupun terlihat bersih (Bahar, 2012:19).

\section{Ragam Hias Lukisan Lukisan Kaligrafi}

Seni Islam dapat dipandang sebagai bentuk ekspresi Qur'ani dalam warna, garis, gerak, bentuk serta suara. Ismail Raji' Al-Faruqi, menyebutkan dalam buku "Seni Tauhid Esensi dan Ekspresi Islam" dibagi menjadi tiga tahapan antara lain: Pertama, Al-Qur'an harus diposisikan sebagai penjelas tauhid atau transendensi. Ajaran tauhid yang terkandung di dalam Al-Qur'an harus diekspresikan secara estetis, baik melalui pola yang tidak memiliki awal maupun akhir, dan memberikan kesan ketakterhinggaan. Prinsip inilah yang menjadi esensi ajaran tauhid di dalam Islam. Demikian halnya dengan seni Islam yang kaya akan aspek infinitas menjadi wadah yang tepat untuk menyelami dan merasakan isi kandungan 


\section{Kalpataru, Volume 7, Nomor 1, Juli 2021 (1-9)}

ajaran tauhid. Kutipan ayat Al-Qur'an mulai digunakan sebagai motif dekorasi pada bendabenda religius, dinding dan bangunan, monumen, tekstil dan juga pada perabotan rumah tangga (Pahala, 2018:7).

\section{Ragam Hias Ukiran}

Lakuer pada dasarnya merupakan bahan finishing yang bertujuan untuk melapisi dan mengawetkan suatu kerajinan khususnya kerajinan kayu. Fungsi yang tidak kalah pentingnya dari lakuer ini adalah dapat memperindah atau memberikan nilai-nilai estetik pada produk kerajinan tersebut. Seni kerajinan lakuer Palembang merupakan kerajinan yang memiliki keunikan tersendiri, yang tidak dimiliki oleh daerah lain pada umumnya, khususnya di Indonesia bagian Sumatera. Seni kerajinan lakuer menunjukkan hasil karya masyarakat Palembang pada masa lampau yang telah berumur ratusan tahun. Menurut sejarahnya, kerajinan lakuer pada awalnya berasal dari negeri Jepang, yang kemudian dikembangkan oleh bangsa Cina. Dari bangsa Cina inilah kerajinan lakuer diperkenalkan kepada masyarakat Palembang, sebagaimana diungkapkan oleh Saragih (2015) bahwa: "Pengerjaan barang-barang lakuer ini untuk pertama kalinya dilakukan di Cina pada masa Dinasti Chou (1027-256 Sebelum Masehi). Berkembangnya kerajinan lakuer di Sumatera Selatan (Palembang) tidak terlepas dari pengaruh budaya Cina dari masa Sriwijaya. Sampai saat ini, kerajinan lakuer masih berkembang secara signifikan. Pengerjaan kerajinan lakuer dilakukan oleh pengrajin tradisional dengan mengandalkan bahan baku yang masih didapat, seperti kayu mahoni, kayu tembesu atau kayu sungkai". Selanjutnya Erwan Suryanegara dalam (Nugraha, 2017) mengungkapkan bahwa: "Menurut sejarahnya kerajinan lakuer Palembang pada awalnya dibawa oleh pedagang dari bangsa Cina dan India sekitar abad ke-6 Masehi yang tujuannya adalah sebagai upeti atau berupa hadiah yang diberikan kepada raja-raja Sriwijaya, sedangkan tradisi menyirih atau menginang di Sumatera Selatan, khususnya di Palembang diperkirakan pada abad ke-6 Masehi hingga abad ke-7 Masehi. Tradisi ini dipengaruhi oleh budaya
Hindu-Buddha yang kemudian disusul oleh bangsa Arab". Berdasarkan ungkapan kedua tersebut, dapat dikatakan bahwa munculnya seni kerajinan lakuer di Palembang tidak terlepas dari unsur budaya yang datang dari luar, dalam hal ini adalah bangsa Cina. Jika diamati dari segi jenis produk dan ragam hias pada kerajinan lakuer, ada beberapa unsur yang mencirikan budaya bangsa Cina seperti bentuk guci dan ragam hias dengan motif hewan (naga dan burung). Bentuk ragam hias seni kerajinan lakuer Palembang terorganisasi melalui unsur garis lengkung, cembung dan spiral sehingga komposisi dan kombinasi unsur tersebut membentuk ragam hias yang dinamis. Bentuk ragam hiasnya tertata sedemikian rupa dengan pola dasar penyusunannya adalah prinsip dasar seni rupa (komposisi, kombinasi, simetris, kesatuan, irama, dan keselarasan/harmonisasi). Keberadaan ragam hias pada seni kerajinan lakuer Palembang, secara keseluruhan cukup dominan, yang mana setiap sisinya memiliki ornamen. Ragam hias pada seni kerajinan lakuer Palembang memiliki bentuk yang berwujud flora dan fauna. Dalam kajian bentuk ragam hias seni kerajinan Lakuer Palembang ini penulis bagi menjadi:

\section{Ukiran Fauna}

Ragam hias fauna (motif binatang). Jika diamati dan ditelusuri dari konteks sejarahnya, ragam hias fauna pada seni kerajinan lakuer tepak sirih Palembang dipengaruhi oleh ragam hias bangsa Cina, seperti motif naga dan burung hong. Ragam hias ini tidak diwujudkan dalam bentuk yang realis, akan tetapi sudah distilir dalam bentuk yang dekoratif (Mubarat, 2016:8).

\section{Ukiran Flora}

Ukiran flora berupa stilasi suluran tumbuh-tumbuhan, terdapat juga ornamen bunga anggur dan pakis. Aplikasi bunga anggur dan pakis diterapkan pada hiasan mimbar. Makna dari sulur-suluran tumbuhan melambangkan kehidupan yang mengandung pengertian suci. Sulur-suluran adalah simbol kesuburan dan kehidupan yang bergerak secara dinamis, suluran tumbuhan dalam kosmologi Hindu merupakan lambang dari kehidupan dan keseimbangan, mengandung makna bahwa untuk memasuki dunia atas harus melalui atau memiliki kesucian dan kesempurnaan. Motif 


\section{Kalpataru, Volume 7, Nomor 1, Juli 2021 (1-9)}

pucuk daun yang melengkung dan berputar adalah simbol kesabaran, selalu tunduk, taat, dan merendahkan diri. 10 warna merupakan elemen yang penting untuk mendukung karya seni. Warna yang digunakan dalam karya ini dominan warna gelap tetapi terkesan natural dengan top coat tampilan doff agar warna karya terlihat lebih elegan. Unsur rupa tekstur yang menunjukan rasa permukaan bahan, tekstur yang ada dalam sifat objek ini yaitu sedikit kasar dan keras, karena menggunakan media akar kayu jati dan bahan lainya (Hidayah, 2019:9-10).

\section{Ukiran Geometris}

Perwujudan budaya fisik (artifact) peninggalan sejarah awal perkembangan budaya Islam di Nusantara utamanya berupa seni bangunan dalam berbagai variasinya. Bangunan makam (batu nisan), bangunan tempat peribadatan (masjid), dan bangunan istana (kesultanan) merupakan unsur penting dalam perkembangan seni bangunan Islam di Nusantara, termasuk di pulau Jawa. Seni bangunan bukan sekadar pernyataan bentuk atau struktur semata, namun juga berperan sebagai institusi budaya, pencerminan sistem nilai dan suatu konsep dan gagasan yang identik dengan corak kehidupan masyarakat pendukungnya. Ragam hias geometris merupakan ragam hias yang memanfaatkan beraneka unsur-unsur garis, seperti garis lurus, lengkung, zigzag, spiral serta bermacammacam bagian seperti sisi empat, persegi panjang, lingkaran, layang-layang juga wujud yang lain sebagai motif wujud dasarnya. Ragam hias geometris sendiri merupakan motif tertua dalam ornamen lantaran telah dikenal sejak zaman prasejarah. Motif geometris berkembang dari wujud titik, garis, atau bagian yang berulang dari yang sederhana hingga pola yang rumit. Ragam hias geometris berupa flora dan fauna tidak sedikit diterapkan kepada kain tenun, kain batik, kain sulam, kain bordir, bangunan hunian, candi-candi, ukiran, perabotan hunian tangga, kerajinan tangan dan sebagainya.

\section{Mihrab Masjid}

Mihrab kini hampir selalu hadir dalam arsitektur masjid. Keberadaannya sudah diterima oleh umum menjadi bagian dari masjid, yakni sebagai penanda arah kiblat. Karena itu, letak mihrab menjorok ke dalam di bagian depan ruangan masjid. Mihrab di Masjid Jami' Sungai Lumpur berada di bagian muka, dan menjadi tempat imam dalam memimpin dalam shalat berjamaah. Dalam bahasa Arab, kata mihrab berarti melawan atau berperang. Beberapa sejarawan menganggap, istilah ini lebih berasal dari Persia, yaitu, lubang yang tidak tembus atau cekungan (niche) pada kuil Mithraistik.

\section{Bedug Masjid}

Bedug di Masjid Jami' Sungai Lumpur diyakini memiliki umur setua bangunan masjid itu sendiri. Bedug dibuat dengan menggunakan kayu gelondongan utuh dan ditutup dengan kulit sapi. Hampir seluruh masjid di Indonesia memiliki bedug, biasanya dipergunakan sesaat sebelum adzan untuk mengingatkan waktu shalat dan mengajak umat Islam shalat berjamaah di masjid. Ada yang berpendapat, bedug terkait erat dengan budaya Tiongkok yang dibawa masuk ke masjid-masjid Nusantara oleh Laksamana Cheng Ho yang kebetulan juga muslim. Namun, bila ditilik dari sisi sejarah, nenek moyang kita sudah mengenal nekara dan moko, semacam genderang untuk ritual minta hujan yang terbuat dari perunggu atau logam lainnya pada zaman dulu (Nugraha, 2017:3-4).

\section{Tongkat dan Bendera}

Di Masjid Jami' Sungai Lumpur khatib saat berkhutbah bertumpu pada tongkat seperti halnya khutbah Jumat di Masjid Agung Palembang memegang tongkat yang terbuat dari kayu ulin. Tongkat khatib yang bersandar pada mimbar masjid. Tongkat berbentuk seperti pena ini berukuran panjang 1 meter bewarna hitam ini penuh dengan beragam ukiran timbul dari ujung hingga pangkalnya (Siswayanti, 2016:345).

\section{Konsep Kosmologi}

Masjid Jami' Sungai Lumpur didirikan di Kelurahan 11 Ulu dimana masyarakat disana pada umumnya bermata pencaharian sebagai pedagang dan petani tentunya dalam beraktivitas sehari-hari dengan memanfaatkan sungai Musi sebagai sarana transfortasi. Pada masa itu masyarakat muslim di sana merasakan bahwa perlunya suatu tempat atau ruangan 


\section{Kalpataru, Volume 7, Nomor 1, Juli 2021 (1-9)}

baru untuk shalat berjama'ah. Sedangkan di daerah seberang Ulu pada waktu itu belum mempunyai masjid sama sekali.

Menurut informasi yang ada Sayid Abdullah bin Salim Alkaff orang yang mendirikan sebuah masjid di Kelurahan 11 Ulu Palembang yang diberi nama Masjid Jami' Sungai Lumpur. Sayid Abdullah bin Salim Alkaff mendirikan Masjid Jami' Sungai Lumpur dengan hartanya sendiri. Beliau pun dikenal sebagai seorang pengusaha yang sukses pada waktu itu usaha beliau ini dapat berjalan dengan baik. Masjid Jami' Sungai Lumpur didirikan di Kelurahan 11 Ulu Palembang. Hal ini dikarenakan penduduk di Kelurahan 11 Ulu cukup padat, di samping itu pula Kelurahan 11 Ulu merupakan pusat industri dan perdagangan di Kelurahan 11 Ulu Kecamatan seberang Ulu 11 Palembang (Paramita, 2018:100).

Masjid Jami' Sungai Lumpur berdasarkan inskripsi di bangunan masjid, dibangun tahun 1872 Masehi. Angka 1872 diabadikan pada ukuran bangunan masjid oleh arsitek bangunan masjid. Luas bangunan utama masjid berukuran $9 \times 9$ meter, angka tersebut diterjemahkan dari angka $1+8=9$ dan angka $7+2=9$. Angka 9 (Sembilan) merujuk pada konsep "Batanghari 9" dan konsep petak 9 . Konsep 9 juga merujuk pada 9 wali, tokoh penyebar Islam di tanah Jawa yang terkenal.

\section{Nilai Akulturasi Budaya}

Masyarakat di Kelurahan 11 Ulu Palembang penduduknya dari berbagai etnis, seperti penduduk asli Palembang dari berbagai daerah dari luar kota, seperti Musi Banyuasin (Muba), Lahat, Muara Enim, Lubuk Linggau, Ogan Komering llir (OKI), Ogan Komering Ulu $(\mathrm{OKU})$, dan orang keturunan Arab dan Cina. Dari berbagai etnis yang paling banyak berdomisili di sini adalah orang Palembang asli ditambah dengan penduduk pendatang (bukan asli Palembang). Adat istiadat, norma dan hukum dalam masyarakat dinilai berharga dan penting, karena nilai-nilai ini menjadi pedoman bagi kehidupan masyarakat. Seperti masyarakat di sekitar Masjid Jami' Sungai Lumpur masih menganut tradisi atau adat istiadat lama yang diwariskan oleh nenek moyangnya secara turun temurun, kegiatan-kegiatan komunitas muslim seperti kegiatan perayaan hari besar, diskusi, kajian agama, dan belajar Al-Qur'an. Kegiatan lainnya seperti Ratib Al-Hadad yang dilakukan setiap hari Jumat yaitu membaca dzikir-dzikir, shalawat dan lain sebagainya yang masih dilaksanakan di Masjid Jami' Sungai Lumpur. Adapun adat istiadat atau budaya yang masih dipertahankan sampai sekarang antara lain: acara ta'ziyah, perkawinan, rebana, ziarah kubur, tahlilan.

Masjid Jami' Sungai Lumpur dahulunya memiliki ikatan yang kuat dengan sungai. Sungai Musi merupakan urat nadi transportasi dan komunikasi. Sungai bagi banyak peradaban telah menjadi hal utama dan terpenting. Bahkan sungai dianggap memiliki tuah dan keramat. Dari sungai inilah kesultanan tersebut bisa membangun kehidupan masyarakat dan bangsanya, sebab peran sungai pada masa itu menjadi arus utama transportasi dan jalannya perekonomian global multi jaringan (Sadzali, 2019:119-124).

\section{SIMPULAN}

Masjid Jami' Sungai Lumpur memiliki nilai sejarah syiar Islam di Kota Palembang pada abad 19 Masehi. Masjid Jami' Sungai Lumpur memiliki nilai budaya berupa nilai tangible dan intangible.

Nilai budaya tangible Masjid Jami' Sungai Lumpur antara lain seni arsitektur bangunan masjid, seni ukiran, seni lukis, benda upacara keagamaan (bedug, bendera, tongkat, panggung kotbah). Nilai budaya intangible Masjid Jami' Sungai Lumpur antara lain: konsep sembilan, konsep kearifan lingkungan pelestarian lahan basah.

Nilai sejarah dan nilai budaya Masjid Jami' Sungai Lumpur dapat dijadikan sumber ajar, materi pengayaan materi penyebaran agama Islam dan sejarah lokal.

\section{DAFTAR PUSTAKA}

Bahar, M. A. 2012. "Evaluasi Terhadap Aspek Kebersihan dan Kesucian dalam Perancangan Arsitektur Masjid". Dalam Journa of Islamic Architecture, 2 (1). 


\section{Kalpataru, Volume 7, Nomor 1, Juli 2021 (1-9)}

Bakti, H. R. 2012. Jejak Sejarah Islam di Bumi Sriwijaya. Palembang: Assiri.

Hidayah, A. N. 2019. Transformasi Ornamen Masjid Mantingan Pada Seni Ukir Kayu. (Doctoral Dissertation, Institut Seni Indonesia Yogykarta).

Mubarat, H. 2016. "Kajian Bentuk Dan Fungsi Seni Kerajinan Lakuer Tepak Sirih Palembang". Dalam Jurnal Seni, Desain dan Budaya, 1 (1).

Nugraha, A. 2017. Pesan Dakwah dalam Budaya Rampak Bedug: Studi Deskriptif Pesan Dakwah dalam Budaya RAMPAK Bedug di Desa Kadumerak Kecamatan Karang Tanjung Pandeglang Banten (Doctoral Dissertation, UIN Sunan Gunung Djati Bandung).

Saragih, Meriati, Warsita, dan Diah A. Deliningtias. 2015. Buku Panduan Museum Negeri Sumatera Selatan. Palembang: Pemerintah Provinsi Sumatera Selatan Dinas Kebudayaan dan Pariwisata.

Sadzali, A. M. 2019. "Antara Sakral dan Profan: Analisis Konsep Budaya Atas Penempatan Makam Kesultanan Indragiri Terhadap Sungai Indragiri". Dalam Khazanah, 85-103.

Siswayanti, N. 2016. Sejarah dan Peranan Masjid Gammalamo Jailolo Halmahera dalam Menyingkap Jejak.

Sholeh, K. 2016. Kemaritiman Sriwijaya. Palembang: NoerFikri Offset.

Sutrisno, A. F., \& Prijadi, R. 2013. "Karakteristik Arsitektur Menara Masjid sebagai Simbol Islam dari Masa ke Masa". Dalam Media Matrasain. 10 (2). 10-19.

Pahala, A. A. 2018. "Resepsi Estetik Pada Lukisan Kaligrafi Sakban Yadi". Dalam Jurnal Tarbiyatuna. 9(1). 1-17.
Paramita, T. 2018. Sejarah Masjid Jami' Sungai Lumpur Kelurahan 11 Ulu Palembang (Studi Analisa Fungsinya Terhadap Penyebaran Islam di Palembang) (Doctoral Dissertation, UIN Raden Fatah Palembang).

Rochmiatun, E. 2017. "Bukti-Bukti Proses Islamisasi di Kesultanan Palembang". Dalam Jurnal Kebudayaan dan Sastra Islam. UIN Raden Fatah Palembang. 


\section{KETENTUAN PENULISAN ARTIKEL JURNAL KALPATARU}

1. Naskah berbahasa Indonesia yang disempurnakan bertemakan kesejarah yang meliputi hasil penelitian sejarah, pengajaran sejarah dan penelitian kebudayaan.

2. Naskah harus asli dan belum pernah dimuat dalam media lain. Naskah dapat berupa hasil penelitian/artikel kajian konseptual yang ditulis oleh perorangan dan atau kelompok.

3. Naskah ditulis dengan cara-cara yang sesuai dengan ketentuan penulisan artikel ilmiah menggunakan bahasa Indonesia yang baku, berupa ketikan, beserta soft file dalam CD-RW atau dengan mengirimkan email pada redaksi jurnal Kalpataru dengan alamat jurnalkalpatarusejarah@gmail.com, spasi tunggal, jenis huruf arial narrow ukuran 12, dengan panjang naskah antara 8-15 halaman pada kertas A4.

4. Artikel hasil penelitian memuat:

JUDUL

Nama Penulis

Abstrak

\section{A. PENDAHULUAN}

B. METODE PENELITIAN

C. HASIL DAN PEMBAHASAN

D. SIMPULAN

DAFTAR PUSTAKA
: XXX (HURUF KAPITAL)

: (disertai jabatan, institusi, dan email)

: (Bahasa Indonesia yang memuat 100-200 kata diikuti kata kunci, dengan jenis huruf arrial narrow dan ukuran huruf 11 serta dicetak miring).

: (memuat latar belakang masalah, tinjauan pustaka secara ringkas, masalah penelitian, dan tujuan penelitian).

5. Artikel Kajian Konseptual memuat:

JUDUL

Nama Penulis

Abstrak

\section{PENDAHULUAN}

Sub Judul

Simpulan

DAFTAR PUSTAKA
: (berisi simpulan)

: (berisi pustaka yang dirujuk dalam uraian naskah).

6. Referensi sumber dalam teks artikel ditulis dengan menggunakan side note, contoh (Jalaludin, 1991:79); sementara penulisan daftar pustaka disusun dengan ketentuan. Nama pengarang. Tahun terbit. Judul (dicetak miring). Kota terbit: Nama Penerbit. Contoh: Koentjaraningrat. 2010. Manusia dan Kebudayaan di Indonesia. Jakarta: Djambatan. Daftar pustaka hanya memuat pustaka/sumber yang dirujuk dalam uraian dan disusun menurut abjad tanpa nomor urut.

7. Naskah yang dimuat akan disunting kembali oleh redaksi tanpa mengubah isinya.

8. Naskah yang ditolak (tidak bisa dimuat) akan dikirim kembali ke penulis dengan pemberitahuan tertulis dari redaksi atau melalui email.

9. Penulis yang naskahnya dimuat akan mendapat 1 (satu) majalah nomor yang bersangkutan.

10. Kontak person: Muhamad Idris (081271498618); Eva Dina Chairunisa (082281267851); Jeki Sepriady (085269261780). 